\title{
Gothic Resistances: Flesh, Bones, Ghosts and Time in Vietnamese Postwar Fiction
}

\author{
John Armstrong
}

National Formosa University, Taiwan

\begin{abstract}
In contrast to the thousands of critical studies of American writing on the Vietnam War, there has been a relative dearth of English-language appraisals of Vietnamese literature of the American War (as it is known in Vietnam). This disparity in understanding partly informs anthropologist Heonik Kwon's distinction between "the idiom of ghost" often used in American memories of the war and the widespread public belief in war ghosts in Vietnam, whose war dead numbered approximately fifty times that of the American military forces, and whose citizens continued to suffer long after the war due to the most extensive bombing and chemical weapons campaigns in the history of humankind.
\end{abstract}

This paper explores novels (by Bao Ninh and Duong Thu Huong) and short stories by (Le Minh Khue, Ho Anh Thai, Ngo Tu Lap and Phan Hy Dong) from the rich wave of Vietnamese postwar fiction which began to be published and translated in the early 1990s. Through close readings of these works, this study will analyse how local customs of the dead combine with Gothic forms and features - flesh, bones, ghosts and time - to create fictional and memorial resistances to myths and ideologies which have sought to cast the war in more traditional tropes of nationalism and heroism.

Keywords: ghosts, Gothic, time, trauma, Vietnamese postwar fiction 
667 he best Vietnam books," says Donald Ringnalda, "are journeys of unlearning...ontological and epistemological meditations, not narrative histories and documents that pretend to 'get it right.' They are the avantgarde books of experimentation and improvisation gone blue collar. And finally, they're all quite deranged, and necessarily and fittingly so" (1994, p. 35). The word "Vietnam" here, however, does not refer to the country or the people who live there, but is rather an adjective denoting a kind of writing that deals solely with the American experience of war in that country. As Jim Neilson points out, "the depictions of the war appearing within critically sanctioned [American] literature woefully misrepresent the heroism and the vast suffering of the Vietnamese and consistently view the war through the narrow prism of American history and culture" (1998, p. 7). And critics, it seems, as well as novelists and poets, have also been largely guilty of this narrow view. Ringnalda's book, for example, does not make even one comparative gesture toward Vietnamese postwar fiction, an incredible omission considering the intertextual overlap of themes and ideas between American and Vietnamese writing on the war, and the opportunity for a more transnational understanding of cultural responses to the conflict. Indeed, in contrast to the thousands of critical studies of American writing on the Vietnam War, there has been a relative dearth of English-language appraisals of Vietnamese literature of the American War (as it is known in Vietnam). This is quite surprising as the English version of Bao Ninh's The Sorrow of War (1995) is studied globally in schools and colleges, and even more so given the diversity of material now available in translation. It is entirely possible that, just as W.G. Sebald argues in the case of Germany after World War II, America's actions in Vietnam and their long-term effects upon the Vietnamese people "have never fully crossed the threshold of the [American] national consciousness" (2004, p. 11). It is partly this void in the American understanding of the war which informs anthropologist Heonik Kwon's distinction between "the idiom of ghost mentioned in American public media" (commonly phrased as "the ghost/specter of the Vietnam War") and the widespread public belief in war ghosts in Vietnam (2008, p. 14), whose war dead number approximately fifty times that of the American forces. Recent critical work has cited the Vietnam War as informing a "comeback" for "War Gothic" in American culture (Soltysik \& Hantke, 2016, p. xviii), but as Kwon argues, American and Vietnamese experiences of the Vietnam/American War were very different. While much American Vietnam War fiction is based on soldiers' experiences in a strange, tropical landscape, Vietnamese postwar fiction is grounded in the suffering of a colonised, occupied and heavily bombed country. These identities, along with Vietnam's religious, superstitious and ancestral practices have led to a postwar literature abounding in horror, ghosts, and haunted memories at once Gothic and traditionally South-East Asian in character. This paper explores novels and short stories from the rich wave of 
Vietnamese postwar fiction which began to be published and translated in the early 1990s in response to state-driven late-socialist commemorations of the war. Through close reading of these works, the study will analyze how some of the genre's most Gothic elements - flesh, bones, ghosts and time - combine with local Vietnamese customs of the dead to form literary and memorial resistances to mythical and ideological rememberings of the war.

\section{Fleshly Horrors and the Demythologizing of Heroism}

To the Western reader and consumer of the horror genre, Vietnamese postwar fiction might seem to have a familiarly ghoulish appetite for corpses and violations of the flesh. The most famous of all Vietnamese war novels, for example - Bao Ninh's The Sorrow of War - begins in the "Jungle of Screaming Souls" (1995, p. 4) with extended configurations of the gore of violent death: "Bloated human corpses, floating alongside the bodies of incinerated jungle animals, mixed with the branches and trunks cut down by artillery, all drifting in a stinking marsh" (1995, p. 5). Kien, the protagonist of the narrative, is working for the Missing In Action remains gathering team in 1975, after the Americans have all but left Vietnam. His grim task of finding the bodies and remains of those fallen is made worse by his having to string his hammock directly above the corpses in the truck. That Bao begins his novel with the gathering of remains is significant for several reasons. Kien is a soldier, then writer, in the different timeframes of the story, and the question of how to remember and represent the myriad horrors of the war is often front and center of the narrative: "his pen takes him closer to at first then more distant from what he wishes to say" (1995, p. 48). Gathering the dead, collecting their physical remains, can therefore be read as a deeply symbolic act in terms of writing. As Bao says of Kien's compulsion to write, "this process of recalling his work in gathering remains had breathed new energy into each page of his novel" (1995, p. 89). Bao's and Kien's war writing, then, function in a similar way to gathering the dead, repeatedly returning to scenes of massacre to tell at least some of the stories of those fallen. Yet Bao's and Kien's memories and stories are also forms of resistance, against both the destructive and disintegrative powers of war itself and the official national and political ideologies and myths under which the war was fought and remembered. ${ }^{1}$

\footnotetext{
${ }^{1}$ In the Foreword to The Culture of Memory: Remaking the Past in Late Socialist Vietnam (2001), John Bodnar writes, "[w]hen the Vietnamese government attempted to honor the dead who had fought the Americans, they cast their commemoration in predictable tropes of patriotism and heroism. Such images, however, held only a limited value for families deeply attached to rituals that signified that the dead would be reborn in another world where they would join a community of ancestors" (p. 10). While some of Kien's memories are of collecting remains for the government MIA program, this paper argues in the same vein
} 
On the surface, Bao's beginning with the first wave of postwar MIA searches would appear to chime with the Vietnamese communist government's postwar interest in commemoration and repatriation of the war dead, which became one of the main priorities of the state in the early postwar years. "The missing bodies of fallen heroes (nhung nguoi mat tich)," says Heonik Kwon, became "a principal instrument for national integration and postwar reconstruction" (2008, p. 48). However, Bao's recounting of remains collection and combat is anything but heroic: "The fallen soldiers shared one destiny," he writes,

no longer were there honorable or disgraced soldiers, heroic or cowardly, worthy or worthless. Now they were merely names and remains.

For some of the other dead, not even that. Some had been totally vaporized, or blasted into such small pieces that their remains had long since been liquidized into mud. (1995, p. 25)

Kwon points out "the centrality of heroic sacrifice in the regeneration of life after destruction" and "the agency of the state as the sole legitimate undertaker to orchestrate the transformation of mass war death" (2008, p. 49). Thus, Bao's own commemoration of the dead is subversive in that his writing follows a trajectory from "destiny" to "mud," from abstract to material, from ideology to flesh. The physical horrors of death in the novel, often visceral and abject (as seen above), are at odds with the ideology of revolutionary struggle and the official myths of glorious martyrdom which retrospectively served to paint the war in a singular, heroic light.

This undercutting of heroism with fleshly horror is also present at the very beginning of Duong Thu Huong's Novel Without a Name (first published in English two years after The Sorrow of War in 1995, having been banned in Vietnam on publication in 1993). Quan, a young platoon captain and the main protagonist of the novel, remembers a mission in the Gorge of Lost Souls (a setting very similar to Bao's The Sorrow of War). The episode culminates with the finding and burial of six dead female soldiers who have been raped, murdered and mutilated. Duong's opening story shares also with Bao's a similar unflinching focus on violations of the flesh. She writes,

as Bodnar, that the personal, familial and literary act of remembering is to some extent a subversive act in terms of its relationship with national ideology and commemoration. 
The soldiers had raped them before killing them. The corpses were bruised and violet. So this was how graceful, girlish bodies rotted, decomposing into swollen corpses, puffy as dead toads. Maggots swarmed in their wounds, their eyes and mouths. Fat white larvae. They crawled over the corpses in waves, plunging in and out of them in a drunken orgy. (Duong, 1995, p. 3)

It would be possible to deride a passage like this as gratuitously gruesome and morbid, with its almost pornographic depiction of physical decomposition in place of the terrible abuse, suffering and murder which must have preceded this aftermath. However, Duong's extended gaze at this deeply disturbing scene has various significant functions. It shows war's utter disregard for the flesh. The passage also draws the reader's attention to the sexual violence faced by Vietnamese women in the war, many of whom were employed as infantry and scouts. ${ }^{2}$ Moreover, it deploys Gothic horror to generate physical feelings of disgust. David Punter defines the horror side of the Gothic in early novels of the genre as more physical (rather than the more psychological aspect of terror); material which treats "the brute facts of rape, violence, murder and so forth" (2014). And furthermore, like Bao's corpse scenes at the beginning of The Sorrow of War (in which bodies are "vaporized," "liquidized" and reduced to "mud"), the physical indignities to which these women's bodies are exposed (multiple penetrations of rape, maggots, and soldiers' and readers' gazes) are a direct rebuttal of notions of glorious, heroic and patriotic death in war. This trope is traceable back throughout twentiethcentury war writing to famous European works such as Eric Maria Remarque's All Quiet on the Western Front (1982) and Wilfred Owen's "Dulce Et Decorum Est" (1994), both ripostes to "the old lie" (Owen, 1994, p.29) of war ideology - the sweet and honorable death for one's country - both replete with their own cocktails of abject physical horror and mud.

Placing these Vietnamese texts in the same comparative field as early twentieth-century European war writing is problematic but illustrates strong resemblances that suggest contiguous and corresponding universal human war experiences, regardless of continent and historical epoch - ones that subsequently create (to a degree) an

\footnotetext{
${ }^{2}$ The representation of rape, sexual violence and the female body is touched upon several times in this paper but is not the main focus. Rather, this study uses the physical violation of rape and its traumatic effects on victim and witness as aspects of a wider discussion of Vietnamese postwar fiction's uses and purposes of the Gothic. Gina Marie Weaver's Ideologies of Forgetting: Rape in the Vietnam War (2010) includes analysis of rape scenes in both Bao's and Duong's novels, where she also reads them as ripostes to political ideologies of war (pp. 28-32).
} 
automatic intertextuality within the field of war literature. Taking All Quiet on the Western Front and The Sorrow of War as exemplary European and South-East Asian popular war novels respectively, their similarities are sometimes striking. Both novels are extended meditations on the use of national myth and the destruction of youth. Both central characters become war weary, cynical veterans, bitter at the older generation and fictitious ideologies for which they have sacrificed almost everything. And more specifically, both novels deploy extended scenes of the nearly dead or virtual living corpses. In All Quiet on the Western Front (1982), Paul Bäumer and his colleagues visit their friend Kemmerich, who is dying from infection after having his leg amputated. "He looks ghastly, yellow and wan," narrates Baumer,

In his face there are already the strained lines that we know so well, we have seen them a hundred times. They are not so much lines as marks. Under the skin the life no longer pulses, it has already pressed out the boundaries of the body. Death is working through from within. It already has command in the eyes.... His features have become uncertain and faint, like a photographic plate from which two pictures have been taken. Even his voice sounds like ashes. (1982, pp. 14-15)

Similarly, in The Sorrow of War, Kien visits Sinh, who is laid paralyzed on a small bed in the back of the tiny family home. Bao writes, "Sinh's hair had all fallen out, revealing a darkening scalp, dry as old timber. His nose had flattened and his cheeks had collapsed, revealing his teeth and eye sockets" (1995, p.77). While Bao's description of this near-corpse stops short of Remarque's death taking "command," both scenes are essentially death-infecting-life representations of the post-combat body. They achieve a sense of horror by transforming young men into living corpses and commingling both sides of the boundary between life and death, creating Gothic bodies through the abject. Famously, in her essay "Approaching Abjection," Julia Kristeva says that "the corpse, the most sickening of wastes, is a border that encroaches upon everything" (2000, p. 543). While not as overt as vampires or zombies, both Remarque's and Bao's nearly dead tap into a horror in the same semantic field as the undead, achieving in the mind of the reader the idea of war as a pollution of young flesh, an abomination allowing death to inhabit life, a Gothic entity in and of itself. ${ }^{3}$

\footnotetext{
${ }^{3}$ In their introduction to the collection of essays War Gothic in Literature and Culture, Agnieszka Soltysik Monnet and Steffen Hantke discuss at length historical, generic and innate relations between the Gothic and war, including the war in Vietnam (2016, p. ix-xxv).
} 
Both Bao and Duong deploy Gothic horror as one way of representing the physical degradations of war. As well as unflinching depictions of dead bodies and scenes of battlefield carnage (both of which abound in these novels), these texts also use the grotesque and the uncanny as modes of representation. Again, Bao's and Duong's methods here are very similar, suggesting intertextuality, common shared experience, and the propensity of war writers to work in the realm of the Gothic in order to impart the often extraordinary nature of human experience in war. In episodes from both novels, the writers depict the killing of orangutans for food. In The Sorrow of War, Kien's squad is spooked after killing an orangutan. "But, oh God," writes Bao, "when it was killed and skinned the animal looked like a fat woman with ulcerous skin, the eyes, half-white, halfgrey, still rolling. The entire squad was horrified and ran away screaming" (1995, p. 7). In Novel Without a Name Quan remembers "the horror of eating Orangutan soup":

Orangutans are large apes, and they bear an uncanny resemblance to human beings. Their eyes can laugh maliciously or flare with hate, pain, or bitterness. Most of all, their hands are smooth and white, like the hands of a two-year-old child. (1995, p. 8)

Both novels here use the uncanny element of the Gothic, exploiting the killing and eating of primates as an almost cannibalistic practice, based on the orangutan's resemblance and relation to human beings. In Freud's thinking, "the 'uncanny' is that class of terrifying which leads back to something long known to us, once very familiar" (2013, Ch. 1). Here, this is achieved by having primate resemble human in death. Duong's version likens the orangutan's severed hands to that of a "two-year-old child," increasing the horror of the situation by indirectly introducing the idea of mutilating and eating children (1995, p. 8). On the one hand, these episodes are simply about survival, details of the harsh and desperate lives of NVA troops during the war. On the other, however, they are symptomatic of what might usefully be called "Jungle Gothic," a particular brand of horror which uses elements of Western Gothic (such as the uncanny) but is wholly dependent on the flora and fauna of a tropical setting. Intermittently, throughout both novels, the jungle is transformed from a place of shelter into a place of terror. There is an "anxiety tree" whose fruit causes "bizarre dreams" and a strange "yearning for death" (Duong, 1995, p. 18); the "rosa canina," a "blood-loving" hallucinogenic plant said to flower best in graveyards (Bao, 1995, p. 12); and a mythical

\footnotetext{
${ }^{4}$ In "Future Gothic,"Nema Montezero lists "jungle-Gothic," as one of many "hybridization-hyphenations" of the Gothic in its seemingly infinite critical usage. Yet "jungle-Gothic" has already been used to good effect in critiques of Evelyn Waugh, Tim O'Brien, Michael Herr (among others) and for a whole sub-genre of Philippine film (2016, p.262).
} 
"jungle monster" with a diabolical human laugh (Bao, 1995, p. 96). Not dissimilar, then, to Western conceptions of the forest as supernatural place, the jungle in Vietnamese war writing is potentially a fearful place (including for native Vietnamese) which, from time to time becomes an active part of, and setting for, the simultaneous composition of abject physical horror and the uncanny.

\section{Individual vs History: Bones, Ghosts, and Ancestral Spirits}

Ironically, the significance of the more physical and fleshly horrors in these texts is probably best understood by exploring the importance of bones and skeletons. Both Bao and Duong include important episodes about skeletons in their novels, as do other Vietnamese postwar writers. ${ }^{5}$ In The Sorrow of War, Kien is haunted by images of his friend Can's skeleton, found by military police after his desertion: "Only his skeleton was complete, like that of a frog, thrown into a mud patch. Crows had pecked away Can's face, his mouth was full of mud and rotting leaves (Bao, 1995, p. 24). Novel Without a Name includes an extended encounter with a skeleton whose spirit draws the narrator/protagonist to its resting place. "So it was you, companion, who held me back here," Quan says. "The dead man's face was frozen in a toothy grin; his teeth were shiny, straight. These were the teeth of a young man" (Duong, 1995, p. 51). These skeletons are, in one sense, Gothic memorials which identify and re-establish the individual lost to the anonymity of what Heonik Kwon calls the "reality of tragic mass death" (2008, p. 4).

Perhaps more than any other story, Phan Huy Duong's "The Billion Dollar Skeleton" (1995) pushes the significance of bones in Vietnamese war writing to its most absurd and allegorical limit. In the hope of locating his missing son, a rich American pays Vietnamese for any bones they can unearth and bring to be tested. By offering money for bones, the billionaire's scheme unearths millions of Vietnamese bones and skeletons and even drives people to murder in the hope of being paid. The prizing of the identity of one American skeleton over so many unnamed Vietnamese is significant for a number of reasons: it allegorises and reenacts the racist ideology with which the American government and military fought their war in Vietnam, whereby Vietnamese

\footnotetext{
${ }^{5}$ The finding and identifying of bones and skeletons has an extra significance in Vietnamese postwar fiction due to the thousands of military personnel and civilians unaccounted for at the end of the conflict and the high priority placed on remains repatriation by both Vietnamese and American governments (Kwon, p. 44-63).
} 
were dehumanised as gooks, dinks, slopes, Charlie, Indians and kills; ${ }^{6}$ it reminds the reader of the huge disparity between the two countries in the number of casualties sustained - approximately two to three million Vietnamese men, women and children, soldiers and civilians, compared with 58,220 American military personnel ('Statistical Information about Fatal Casualties of the Vietnam War': n.d.); and in its simple differentiation between one named American and thousands of unidentified Vietnamese bones, it offers at least some recognition of the scale of loss (in the sense of bereavement) and the sheer number of those actually lost (in the sense of not found) to the war. At the end of the story, the piles of bones are so large that when they are burned the toxic smoke and dust cover the whole country. Phan writes, "Ashes rained to the earth. Not a single rice paddy was spared. Ash suffused the air, dusting the trees, the plants, the flowers, penetrating every human dwelling. It blinded the eyes, blocked the nose, stuck in the throat" (1995, p. 229). These apocalyptic scenes replay the aftermath of bombing and chemical poisoning of the Vietnamese people and countryside. The skeletons, then, in all of these texts to differing degrees, function as physical artifacts of Vietnam's and America's losses in the war, and as individual responses to the postwar importance on both sides placed on recovery and repatriation of human remains to serve national and ideological ends. ${ }^{7}$

Towards the end of "The Billion Dollar Skeleton," however, an old man who knows the location of his son's remains thanks the billionaire for helping to find the bones of the war dead and returning the spirits to their ancestors (Phan, p. 229). His gesture reflects how the many unearthed bones and full skeletons in Vietnamese fiction have meaning beyond their physical and symbolic remains. Both their solitary abandonment, and their being found, have ghostly and spiritual ramifications which fall within Gothic and traditionally superstitious modes of thought. In Vietnamese conceptions of death and the dead, there are good deaths and bad deaths. Good deaths in general take place peacefully at home, in the presence of the family. These are called chet nha. This in itself, of course, is not a purely Asian or Vietnamese sentiment. Public announcements of death in Western culture commonly emphasise dying at home surrounded by family as a way of expressing a gentle, smooth passing from the living world to that of the

\footnotetext{
${ }^{6}$ Many studies have explored or touched upon the racism with which America fought its war in Vietnam. Most recently, in Ken Burns's and Lynn Novik's epic documentary series The Vietnam War, the narration and the veteran interviewees have highlighted racism as a major factor in both the ideology behind the war and in the fighting itself (2017).

${ }^{7}$ Heonik Kwon, Ghosts of War in Vietnam (2008, p. 49): "The fate of the MIA was central to the legacy of the American War ... just as it was to that of the Vietnam War. Their bodies became an object of great importance across the frontier, in the cultural politics of nationalism on one side and the geopolitics of cold war (and related domestic cultural politics of anticommunism) on the other."
} 
dead, regardless of religious or secular beliefs. But in Vietnam, deaths away from home, those of a more sudden or violent nature, also have their own specific categorization: chet duong, literally translated, "death in the street." It is commonly believed that those who suffer this kind of death (soldiers in combat, for example) are unable to make a smooth transition from the living world to the world of spirits. Thus their souls are thought to wander as ghosts, caught between this world and the next. These ghosts are sometimes called linh hon (wandering souls), and they are the most likely to haunt and bother the living, frustrated or angry, as they might be, by their interstitial predicament. ${ }^{8}$ Again, for consumers of horror films and ghost stories from all continents, the idea of a restless or angry spirit caught between two worlds and thus haunting the living is a familiar concept. However, where Western culture might commonly view these ghosts in fearful, vengeful revenant terms, the Vietnamese perception of these ghosts is often of a far more practical and pragmatic nature, as entities with needs and grievances, or as Heonik Kwon calls them, "uprooted, placeless beings," or "ontological refugees" (2008, p. 16). Even this rudimentary understanding of a fraction of Vietnam's complex culture of the dead must engender an alarming reconsideration of those statistics which put the number of Vietnamese war dead at between two and three million. Alongside the hundreds of thousands of living refugees from the American War, then, there were (in the minds of many Vietnamese) also millions of homeless dead, wandering the countryside, hoping for their spirits to be returned home and settled.

With these ideas in mind, Vietnamese postwar fiction's abandoned bodies, bones and skeletons take on a much greater significance. In the short story "Tony D" by Le Minh Khue (1995), Old Thien is haunted when his son Than brings home the skeleton of a dead American soldier he intends to sell for repatriation. The father and son's hopes of the skeleton fetching big money are overwhelmed by their harassment from the spirit of Tony $\mathrm{D}$ (the American soldier known only by his dog tags) who appears as a skeleton in their dreams. Old Thien's attempt to placate the ghost of Tony $D$ is an illustration of Vietnamese fears about chet duong ("death in the street"):

If you're all-powerful and all-wise, please rest in peace. Tomorrow my son will find a way for you to return home. He's doing a good deed, sir-nothing evil. You'll be returned to your father, your mother, your wife, and children-it's better than being left in the jungle. (1995, p. 217)

\footnotetext{
${ }^{8}$ This paper's brief discussion of Vietnamese traditional cultures of ancestors, ghosts and the dead is based on, and indebted to, two main sources: Heonik Kwon's Ghosts of War in Vietnam (2008) and Judith Mann's Spirit Realms of Vietnam Volume 1 (2012).
} 
Old Thien's application of traditional Vietnamese ghost-thought to American remains highlights how, in the Vietnamese cultures of the dead, issues of race and ideological enmities of war are completely usurped by familial concerns: "father...mother ...wife...children." The potentially Gothic situation of the haunting is overridden by Thien's working out of what the ghost wants and needs. Likewise, in the skeleton episode from Novel Without a Name (discussed earlier), Quan's finding of the bones is preceded by his being lost for days in a "haunted labyrinth" of giant red colocassius trees, where he hears ghostly "strains of a bamboo flute" (Duong, 1995, pp. 50- 51). When he later finds the skeleton and the soldier's knapsack, there is a bamboo flute inside, suggesting the ghostly music was not simply imagined but part of a real haunting. Also inside is a card which reads "To the Comrade Who Finds This Sack: Please bring it back to my mother, Madame Dao Thi Lo, 68 years old, Em Mo Hamlet, Phung Commune. Thanks" (Duong, 1995, p. 55). The episode, when taken as a whole, is another example of the tendency in Vietnamese postwar fiction to use ghosts in both Western Gothic and locally traditional modes. The mystery and sense of fear as Quan is lost in a "haunted labyrinth" at the beginning of the tale is replaced with the materiality of the note containing the mother's address, and the understated "Thanks." The request of the dead man and Old Thien's attempt to placate the spirit of Tony D reflect Vietnamese ideas about chet duong (death in the street), linh hon (lost or wandering souls) and the practical concerns of ghosts as "ontological refugees" (Kwon, 2008) rather than the often fearful, dreaded spirits of Western stories of the supernatural.

The concerns and suffering of linh hon (wandering souls) and ghosts who have experienced chet duong ("death in the street" or death away from home) are also explored by Ngo Tu Lap in "Waiting for a Friend" (1995). Ngo's story is narrated by a soldier who suffered a death of extreme violence when his whole squad, apart from one, was blown to pieces by heavy artillery. The ghost narrates, in a very candid way, the destruction of his own body:

My corpse is at the foot of the Dun mountain, pinned underneath a gray rock that is shaped like the head of an elephant and covered now with luxuriant foliage. Most of my corpse that is: my feet were burned to ashes under the wrecked tank and my head blown away to the edge of a stream. From there the floodwaters floated it out to the Cai River along with the branches of trees that had been torn off by artillery shells; it was carried along, bobbing and sinking and bobbing up again, almost to the sea. Eventually it came to rest between two big roots. 
These days large prawns make their home in its eye sockets. (Ngo, 1995, p. 201)

The ghost's description of his own death and corpse is intriguing in several different ways. Any Gothic potential is undermined with the matter-of-fact and almost comic tone with which the decapitated head is shown as "bobbing, sinking and bobbing" along before it becomes an underwater home for "large prawns." As well as being a further example of the prosaic way in which death is sometimes viewed in Vietnamese culture, the casual attitude shown to the dispersal of the corpse is again a riposte to the national postwar obsession with the repatriation of human remains. This continues when the ghost describes his friends as less lucky, their unidentifiable bones having been collected and thrown together "haphazardly, then stuck into nylon bags" and buried in a cemetery (1995, p. 202). "But to us," he says, "words on tombstones, paper tokens, and floral wreaths all mean nothing" (1995, p. 202). The ghost's words show how commemorations of the war dead ("paper tokens and floral wreaths"), while thought to placate grievous or restless spirits, are very much a remedy for the living. The American horror writer Peter Straub expresses a similar attitude in Koko (2008). Faced with the newly completed Vietnam War Memorial, veteran Michael Poole is unimpressed: "Here was what was left of the war...names etched into the memorial and the crowd either passing back and forth or standing looking at them" (2009, p. 12). Likewise, the ghost in Ngo's story is dismissive of commemoration and remembrance; instead, he says, "Oblivion-this is where I find my greatest comfort" (1995, p. 201). Thus the "Waiting" in "Waiting for a Friend" is the true predicament of the ghost, in this case the limbo experienced while waiting for the final member of the squad to die and join his lost comrades. The personal ghost narrative of unheroic death, the ignominious end for the corpse, and loyalty shown to the platoon rather than official commemoration are symptomatic of the importance of ghost stories in Vietnamese postwar fiction. Written in an era when official historians were intent on retrospectively creating a "national essence (quoc tuy)" (Pelley, 2002, p. 140) based on a history of resistance to foreign aggression, this kind of ghost story, which focuses on the suffering of individuals and small groups, can be seen as a literary act of subversion, a narrative which resists overarching, homogenous, national metanarratives. ${ }^{9}$

\footnotetext{
9 Jean-Francois Lyotard's famous "incredulity toward metanarratives" (p. xxiv) is relevant here, as the communist project of reunification in Vietnam can be read as a systematic organizing of complex history towards a singular ideal of modernity. In this light, these postwar novels and stories, and their ghosts, are simultaneously postmodern and subversive by setting tales of unheroic death and individual suffering against the monolithic postwar historiography of the state which sought to promote heroic tales of sacrifice and glorious martyrdom. Steven P. Liparulo has argued that The Sorrow of War and Novel
} 
However, as in general Vietnamese worship of the dead, ghosts of war account for only one side of postwar fiction's use of the spirit world. While ghosts in Vietnamese votive practice are considered co bac (aunties and uncles) or simply strangers, ancestors are ong ba (grandparents), and their roles may often be less individual and more conservative and ideological in nature. This tension in the role of spirits forms part of the narrative of Duong Thu Huong's Novel Without a Name. As well as encountering the skeleton and spirit of a lost soldier, Quan is visited by a "wraith" who claims to be an "ancestor, from the seventieth generation" $(1995$, p. 254). Their meeting is an illtempered one in which the wraith tries to inspire the war-weary Quan with tales of fending off "Chinese barbarians" and the building of "triumphal arches" (1995, p. 255). Quan, however, is not impressed. He says: "I don't give a damn about your triumphal arches, or you. Stop bothering me. I've had enough" (1995, p. 257). The encounter with the wraith, aside from adding a further supernatural aspect to the text, draws the reader's attention to the clash between personal narrative and national ideology and history. The wraith personifies the mythic "national essence" of a unified family-state forged over millennia of struggle against foreign invaders. Quan's resistance to the wraith is thus a subversive act which places the importance of the individual story of suffering over national myths of heroism and sacrifice. The Vietnamese two-sided structure of the world of the dead - which includes family and ancestors on the one side, and ghosts and strangers on the other - thus contains opposing meanings in its appearance in fiction. ${ }^{10}$ While the spirits of ancestors often appear as forces of conservatism and tradition, ghosts of the war dead are mostly isolated figures whose stories run counterpoint to official history and ideology, which, according to Patricia M. Pelley, sought to "reorient...loyalties toward broader entities and ideally toward the nation" (2002, p. 157).

Without a Name both "include startlingly similar "postmodern" elements - specifically, self-conscious metafiction, generic heterogeneity, and ambivalence towards the type of story they are telling - war story or love story?" (2002, p. 72). I would add ghosts to his list of postmodern elements as they are crucial to the subversive and refutative nature of these stories. Maria Beville argues that "gothic postmodernism maybe regarded as the voice of the unspeakable terrors of postmodernity, a link to the long lost sense of heterogeneity that is vital to the subjective self" $(2009$, p. 56). While this chapter does not explore the postmodernism of Vietmese postwar fiction, testing its use of Gothic elements as forms of resistance to political narratives naturally steers the argument in that direction. This note is therefore to show how Vietnamese postwar fiction's Gothic overlaps with postmodernism.

${ }^{10}$ For instance, Kwon, in Ghosts of War, notes: “...I introduce the two-sided structure of commemorative ritual, consisting of placed gods and ancestors on one side and displaced ghosts of tragic death on the other" (2008, p.8). 


\section{War Trauma and Gothic Time}

Different functions and significances aside, ghosts of the war dead and spirits of ancestors, have in common a tendency to affect time and the temporality of Vietnamese postwar texts. Their appearance almost always informs some malfunction, rupture or anomaly in the calendrical passing of time. It is not surprising, then, that the postwar fiction of a country like Vietnam - with its long history of colonization and invasion (by French, Chinese and American forces), its huge numbers of war dead, as well as those injured and poisoned by unprecedented military aggression (including the use of chemical weapons and one of the most extensive bombing campaigns of the twentieth century) - should bear the temporal hallmarks of individual, social and national trauma. ${ }^{11}$ Judith Mann has argued that "Vietnamese social memory was ripped apart by the wars [French and American]" (2012, ch.3), suggesting psychic wounding on an individual, collective, and national scale. And it is often through trauma that war gothicises time in fiction with situations in which the dead walk and speak, the past returns at its own volition, and temporal uncertainty and confusion replace simple lineal progression through minutes, hours, days and so forth. ${ }^{12}$ Cathy Caruth's work is pertinent to the idea of gothicised time in postwar fiction, as she puts forward the notion of trauma's "haunting power" of possession, "the literal return of the event against the will of the one it inhabits" (1995, p. 4-5).

This mix of war, experience, trauma, and time creates a dysfunctional equation, the representation of which forces writers to configure temporal arenas in which pasts, presents and futures may exist simultaneously without narrative sovereignty over each other. Bao Ninh's The Sorrow of War features Gothic temporal dysfunction stemming from trauma. Its central character is persistently haunted by the extreme violence of his wartime experiences. At one point in the story, the war returns to Kien in a physical manifestation:

each man in his platoon reappeared before him in the room. By what magic was this happening to him? After the horrible slaughter which

\footnotetext{
${ }^{11}$ Adam Piette has made the point that "The bombing campaigns after LBJ's operation rolling thunder were as close to nuclear events as conventional bombs could muster. The massive explosive ordinance dropped on the jungles was accompanied by the ten-year RANCH HAND operation" (2012, p. 164).

${ }^{12}$ The idea of "gothicised time" is essentially the same as "gothic time," which John Sears describes as "a version of 'time out of joint,' in the sense that historical sequence is unhinged by the logics of haunting and spectrality that mark the Gothic text" $(2011$, p. 6).
} 
had wiped out his battalion, how could he see them all again? The air in his room felt strange, vibrating with images of the past. Then it shook, shuddering under waves of hundreds of artillery shells pouring into the Screaming Souls Jungle, and the walls of the room shook noisily as the jets howled in on their bombing run. (1995, p. 85-86)

The scene re-enacts Caruth's notion of the traumatic event's literal return; unlike a simple flashback or dream, elements of Kien's war experiences affect the physical environment of his postwar life, with his room "vibrating" and "shuddering." Throughout the text, Kien is haunted by various figures and scenarios from his time in the war: the rape by American soldiers of a female scout who saves his squad from being found and killed (1995, p. 191); the abused corpse of a naked female fighter at Saigon Airport, whose "apparition" "appeared before him, her chest white, her hair messy, her dark eyes swarming with ants, and on her lips a terrible twisted smile" (1995, p. 108). The Sorrow of War shifts through temporal zones - pre-war, wartime and postwar - without chapters or the privileging of one narrative timeframe over another. Indeed, part of Kien's post-traumatic stress is his haunting by time itself, subject as he is, to any event and moment of his life at any given instant.

War's gothicising of time in Vietnamese postwar fiction not only deals with the traumatic return of extreme events; rather, it seems that war, as the central experience of the main protagonists, affects all time and can make any memory traumatic. Bao's protagonist Kien, for example, is haunted by happier memories of his pre-war years, as well as the darker experiences of the war. His pre-war romance with his childhood sweetheart Phuong operates as a temporal idyll whose persistent return, rather than a relief, is a torturous token of what has been lost. "The sorrow of war," writes Bao, "was in a strange way similar to the sorrow of love. It was a kind of nostalgia, like the immense sadness of the world at dusk. It was a sadness, a missing, a pain which could send one soaring back into the past" (1995, p. 94). This passage helps the reader to understand the importance of the word "sorrow" in the title of the book. "Sorrow," here, could almost be replaced with "trauma," and the meaning would be essentially the same. The "sorrow" that Bao refers to is a combination of emotions which, like trauma, has the ability to affect time and "send one soaring back into the past." The sorrow/trauma of love/war combined, is fully realised toward the end of the book when Kien remembers how Phuong is brutally raped on a train during an American air raid. In the immediate aftermath of this doubly traumatic event (rape and bombing), Kien confusedly suggests bandaging to stem the flow of blood on Phuong's legs, but she angrily stops him: "Can't you see it's not a wound! It can't be bandaged!" (1995, p. 204). 
The symbolism of Phuong's words ironically encapsulates the war-trauma-time nexus. Her rape is both hers and Kien's trauma, as her virginity is essentially and violently lost to war, and the rupture of her hymen prefigures the violation of Kien's future. It is a wound but it cannot be bandaged, just as the traumatic events of rape and war cannot be un-experienced. As Kien's memory of the incident confirms, Phuong's rape is a war trauma which will exist through time, inhabiting Kien's present and future while dragging him inexorably into his past, where even his idyllic memories - such as swimming with Phuong in a Hanoi lake (1995, p.132) - have become sorrowful, traumatic and haunting.

This is also true of Duong's Novel Without a Name, in which Quan's horrific wartime experiences are punctuated by gothicised hallucinations and dreams from his life before the war. The birth of his baby brother, for example, first appears as a happy memory: The nun and the midwife start to laugh. My mother laughs too. Her teeth sparkle like jade. I always loved my mother's laugh. I cry out with happiness. 'I have a baby brother' (1995, pp. 14-15). Later in the novel, these memories have become infected by Quan's war experiences:

I see my mother seated on the landing of our house, her legs spread apart, offering her breast to a skull. I see her breasts, so familiar, taut and round, soft, with their tiny, rosy nipples. She presses a nipple between the rows of skeleton's white teeth.

She sings. 'Bong bong. Bong bong. Bong bong ...'

I hear her lullaby float up into the sky. I watch the sky drip a golden light.

My brother is dead. Why is she nursing him? She pushes the nipple between his dried-out teeth. She weeps. Her tears fall into the black sockets. The skeleton keeps its teeth clenched.

'Bong, bong. Bong bong. Bong bong ...' (1995, p. 193-194)

The horror of this hallucination is informed by its familiarity. The happy, maternal and familiar sight of Quan's mother breastfeeding his baby brother and singing a simple lullaby appears almost the same, but with the uncanny twists of the skeleton instead of the baby and the mother weeping tears into its eye sockets. The memory of the baby 
brother and his later death in the war have become conjoined in a Gothic nightmare so that Quan is no longer able to separate the memories and differentiate between the two. His happier pre-war memories have mingled with traumatic experiences of the war so that time and memory themselves are traumatised and gothicised. The sufferer of war trauma, in this case the character Quan, like Bao's Kien, is not only haunted by his war experiences, but also other (even positive) experiences which have been infiltrated and infected by the war.

The gothicising of time and memory, it would seem, are both multi-functional and necessary for the representation of war, whether in simple idioms and overused journalistic phrases like "the specter of the Vietnam War," or in the complex versions of trauma explored here. But in considering the Gothic in Vietnamese postwar fiction, it is impossible to forget Kwon's simple, salient point that the fighting "took place mainly in the land of Vietnam and that it is the Vietnamese who count the vast majority in the list of the war dead" (2008, p. 14). So, Gothic time in Vietnamese postwar fiction is also predicated by Vietnam's greater and longer suffering during and after the conflict. In Ho Anh Thai's Behind the Red Mist (2007), the haunting moves backwards and forwards as a young man born towards the end of the war travels back in time to haunt the past. The catalyst for this temporal anomaly is the partial collapse of a Hanoi apartment building completed during the American war. Seventeen-year-old Tan rescues his grandmother from the building before re-entering to search for other survivors. While in the damaged building he is electrocuted by exposed wire, and during his ensuing two-month coma, travels back to 1967. During his stay in the past he is instrumental in his parents' courtship, he exposes a fraudulent fortune teller who tries to use his knowledge of the future, he experiences the full force of an American B52 air raid, and he discovers how a local hero and dignitary is responsible for the overseeing of the building which will collapse in 1987. Like Kurt Vonnegut's Billy Pilgrim who "has come unstuck in time" (2000, p. 19), Ho's protagonist Tan is "displaced in time" (Ho, 2007, p. 124). The important difference between the two characters, however, is that Billy Pilgrim is a war veteran, while Tan is a war baby with little or no experiences of war and no recollection of wartime events. The collapse of the building constructed during the war (which prefigures a collapse of time itself in the story) and the haunting of wartime by a ghost from the future are representative of war's physical and psychological relations with time. In her discussion of temporality in East Asian ghost films, Bliss Cua Lim argues that "ghost narratives productively explore the dissonance between modernity's disenchanted time and the spectral temporality of haunting in which the presumed boundaries between past, present, and future are shown to be shockingly permeable" (2001, p.288). In Ho's story (and the other stories analyzed here), temporal boundaries are also permeable 
and no single temporality holds sovereignty. The collapsed building's physical defects are caused by local wartime corruption and profiteering, whilst Tan's haunting of the past and first-hand experience of the war's effects upon his parents, grandparents and local community reflect the generational trauma brought about by the conflict. As Gabriel Schwab argues, "legacies of violence not only haunt the actual victims but are also passed on through the generations" $(2010$, p. 1). When Tan is coming out of his coma, he overhears one doctor saying to another, "perhaps man has the ability to biologically pass on his memory to future generations" (2007, p. 219). Ho's novella, like Bao's and Duong's novels, explores the intersection of war and time, and again finds that the physical fault-lines are long-lasting rather than temporary. The psychological traumas of an invaded, occupied and bombed country may be passed on to future generations, and trauma experienced individually, communally, and on a massive scale has reconfigured time in cultural memory.

\section{Coda: After the Last Shot is Fired}

While this paper has concentrated almost entirely on the Vietnamese experience of the American War, a final assessment of Vietnamese postwar fiction's engagement with the Gothic is probably best considered comparatively in light of Heonik Kwon's distinction between America's "idiom of ghost" (concerning the lingering memory of failure in a foreign conflict) and Vietnam's experience of the war on its own soil and the incalculable physical damage sustained by land and people. The very fact that only an approximate number of Vietnamese war dead can be counted, in contrast to America's exact figure nominally etched in stone, is itself a telling difference. This is not to belittle the war experiences of American veterans, but rather to think about how trauma on a national level resides partly in a country's cultural production and memory of the event. In Vo Thi Hao's short story "The Blood of Leaves" (2010), a man finds out that his friend has been diagnosed with cancer, like many he has known before. "A pulse of nausea rose in my throat," he says, "each time I remembered the knots of green worms writhing in death from Agent Orange. Faced with such human cruelty, each of us was just like those worms" (2010, p. 134). In his preface to Family of Fallen Leaves (the anthology containing this story), the American poet John Balaban reminds us that "Wars, as we continue to forget, do not end when the last shot is fired" (2010, Preface, p. xii). By its very nature of dealing in death and destruction, war creates ghosts and is therefore ineluctably aligned with the Gothic to some degree. But as the extract from Vo's story shows, war's propensity to continue after "the last shot is fired" can be as physical as it is psychological and memorial. And the war in Vietnam is arguably a special case, enough so for at least one documentary maker to call his film Vietnam: American 
Holocaust (2008). The novels and stories discussed here testify to this. They bear the unique hallmarks of trauma suffered by a largely agrarian, undeveloped country attacked by a technological superpower that sent a man to the moon while running its war in South-East Asia. In a contemporary global society, the American experience of the war in Vietnam has to be (re)considered alongside Vietnam's more extreme domestic experience of the conflict, the country's politics, and its superstitious and religious beliefs concerning death and ghosts. This consideration reveals the Gothic in Vietnamese postwar fiction (along with the country's traditional identities, beliefs and practices) simultaneously informing and inhabiting the representation of flesh, bones, spirits and time as a mode of resistance to the false narratives of idiom, myth and ideology. 


\section{References}

Arison III, L. H. (2009). Statistical summary of herbicidal warfare in Vietnam. $15^{\text {th }}$ field artillery regiment: fighting fifteenth. Retrieved from www.landscaper.net/agent2.htm

Balaban, J. (2010). Preface. In C. Waugh \& L. Huy (Eds.), Family of fallen leaves (pp. xi-xiv). Athens and London: University of Georgia Press.

Bao, N. (1995). The sorrow of war. (T. H. Phan, Trans.) New York: Riverhead Books. (Original work published 1991)

Beville, M. (2009). Gothic postmodernism: Voicing the terrors of postmodernity. New York, NY: Rodopi.

Bodnar, J. (2001). Foreword. In T. H. T. Hue (Ed.), The culture of memory: Remaking the past in late socialist Vietnam (pp. ix-xi). Berkeley and Los Angeles: University of California Press.

Burns, K. \& Novik, L. (Directors). (2017). The Vietnam war [television series]. Florentine Films.

Caruth, C. (1995). Introduction. In C. Caruth (Ed.), Trauma: Explorations in memory (pp. 3-12). Baltimore: The Johns Hopkins University Press.

Claiborne, C. (Writer, Director). (2008). American holocaust [Motion picture]. Linux Beach Productions.

Duong, T. H. (1995). Novel without a name. (H. D. Phan \& N. McPherson, Trans.). New York: Penguin. (Original work published 1993)

Freud, S. (2013). The uncanny. [Kindle version]. Retrieved from Amazon.com.

Ho, A. T. (2007). Behind the red mist. (Q. D. Nguyen Trans.). Willimantic: Curbstone Press. (Original work published 1998)

Kristeva, J. (2000). Approaching abjection. In C. Cazeaux, (Ed.), The Continental Aesthetics Reader (pp. 542-562). London, UK: Routledge.

Kwon, H. (2008). The ghosts of war in Vietnam. Cambridge, UK: Cambridge University Press.

Le, M. K. (1995). Tony D. In W. Karlin, M. K. Le \& V. Truong (Eds.), The other side of heaven: Post-war fiction by Vietnamese \& American writers (pp. 210-222). Willimantic: Curbstone Press.

Lim, B. C. (2001). Spectral times: The ghost film as historical allegory. Positions: East Asia Cultures Critique, 9(2), 287-329. Retrieved from https://escholarship.org/uc/item/1np6b51p

Liparulo, S. P. (2002). Incense and ashes: The postmodern work of refutation in three Vietnam war novels. War, Literature and the Arts 15, (1.2), 71-94. Retrieved from http://wlajournal.com/wlaarchive/15_1-2/liparulo.pdf

Lyotard, J-F. (1984). The postmodern condition: A report on knowledge. (G. Bennington \& B. Massumi, Trans.). Manchester, UK: Manchester University Press.

Mann, J. (2012). Spirit realms of Vietnam volume 1 [Kindle Version]. Retrieved from Amazon.com.

Monnet, A. S. \& Hantke, S. (Eds) (2016) War gothic in literature and culture. New York, NY: Routledge.

Montezero, N. (2016). Future gothic. In W. Hughes, D. Punter \& A. Smith (Eds.), The encyclopedia of the gothic, Chichester: John Wiley \& Sons.

Neilson, J. (1998). Warring fictions: Cultural politics and the Vietnam War narrative. 
Jackson: University of Mississippi Press.

Ngo, T. L. (1995). Waiting for a friend. In W. Karlin, M. K. Le, \& V. Truong, V. (Eds.), The other side of heaven: Post-war fiction by Vietnamese \& American writers (pp. 201-203). Willimantic: Curbstone Press.

Owen, W. (1994). The war poems of Wilfred Owen. J. Stallworthy (Ed.). London, UK: Chatto \& Windus.

Pelley, P. M. (2002). Postcolonial Vietnam: New histories of the national past. Durham and London: Duke University Press.

Phan, H. D. (1995). The billion dollar skeleton. In W. Karlin, M. K. Le, \& V. Truong (Eds.), The other side of heaven: Post-war fiction by Vietnamese \& American writers. Willimantic: Curbstone Press, 1995, pp. 223-230.

Piette, A. (2012) The fictions of nuclear war, from Hiroshima to Vietnam. In A. Piette \& M. Rawlinson (Eds), The Edinburgh companion to twentieth-century British and American war literature Edinburgh: Edinburgh University Press.

Punter, D. (2015, December, 20). The gothic: A lecture [Video file]. Retrieved from https://www.youtube.com/watch?v=fdgDoT8LJaM

Remarque, E. M. (1982). All quiet on the western front. New York, NY: Ballantine Books.

Ringnalda, D. (1994). Fighting and writing the Vietnam War. Jackson: University Press of Mississippi.

Schwab, G. (2010). Haunting legacies: Violent histories and transgenerational trauma. New York, NY: Columbia University Press.

Sears, J. (2011). The gothic of Stephen King. Cardiff: University of Wales Press.

Sebald, W.G. (2004). On the natural history of destruction. New York, NY: Random House.

Statistical information about fatal casualties of the Vietnam War: Electronic reference report. (2016). National Archives. Retrieved from www.archives.gov/research/military/vietnamwar/casualtystatistics.html

Straub, P. (2009). Koko. New York, NY: Anchor Books.

Vonnegut, K. (2000). Slaughterhouse 5. New York, NY: Vintage.

Weaver, G. M. (2010). Ideologies of forgetting: Rape in the Vietnam war. New York, NY: State University of New York Press.

Vo, T. H. (2010). The blood of leaves. In C. Waugh \& H. Lien (Eds.), Family of fallen feaves (pp. 134-146). Athens and London: University of Georgia Press. 